\title{
Arsenate Retention by Epipsammic Biofilms Developed on Streambed Sediments: Influence of Phosphate
}

\author{
D. M. Prieto, ${ }^{1}$ R. Devesa-Rey, ${ }^{2}$ D. A. Rubinos, ${ }^{1}$ F. Díaz-Fierros, ${ }^{1}$ and M. T. Barral ${ }^{1}$ \\ ${ }^{1}$ Department of Soil Science and Agricultural Chemistry, Facultad de Farmacia, Campus Vida, 15782 Santiago de Compostela, Spain \\ ${ }^{2}$ Defense University Center, Escuela Naval Militar, Plaza de España 2, 36920 Marín, Spain \\ Correspondence should be addressed to D. M. Prieto; diego.martina@usc.es
}

Received 27 June 2013; Accepted 7 August 2013

Academic Editor: Ana Moldes

Copyright (c) 2013 D. M. Prieto et al. This is an open access article distributed under the Creative Commons Attribution License, which permits unrestricted use, distribution, and reproduction in any medium, provided the original work is properly cited.

\begin{abstract}
Natural geological conditions together with the impact of human activities could produce environmental problems due to high As concentrations. The aim of this study was to assess the role of epipsammic biofilm-sediment systems onto As (V) sorption and to evaluate the effect of the presence of equimolar P concentrations on As retention. A natural biofilm was grown on sediment samples in the laboratory, using river water as nutrient supplier. Sorption experiments with initial As concentrations 0, 5, 25, 50, 100, 250, and $500 \mu \mathrm{g} \mathrm{L}^{-1}$ were performed. The average percentage of As sorbed was $78.9 \pm 3.5$ and $96.9 \pm 6.6 \%$ for the sediment and biofilmsediment systems, respectively. Phosphate decreased by $25 \%$ the As sorption capactity in the sediment devoid of biofilm, whereas no significant effect was observed in the systems with biofilm. Freundlich, Sips, and Toth models were the best to describe experimental data. The maximum As sorption capacity of the sediment and biofilm-sediment systems was, respectively, 6.6 and $6.8 \mu \mathrm{g} \mathrm{g}^{-1}$ and 4.5 and $7.8 \mu \mathrm{g} \mathrm{g}^{-1}$ in the presence of P. In conclusion, epipsammic biofilms play an important role in the environmental quality of river systems, increasing As retention by the system, especially in environments where both As and P occur simultaneously.
\end{abstract}

\section{Introduction}

Arsenic (As) is a ubiquitous contaminant which is widely distributed in the environment. Due to its toxicity, its presence in soils, sediments, and water, even at very low concentrations, may cause serious health hazards, increasing the incidence of cancer and dermatological, vascular, and cerebrovascular diseases. For this reason, it was one of the first chemicals recognized as carcinogens [1]. It is estimated that 40 million people worldwide are at risk from drinking As-contaminated water [2]. Several cases of people affected by As pollution have been reported; thus, for example, thousands of arsenic poisoned patients were identified in Bangladesh, suffering from skin lesions and gangrene in legs as well as various types of cancer [3]. Consequently, the World Health Organization (WHO) has set the level of arsenic allowed at $10 \mu \mathrm{g} \mathrm{L}^{-1}$ in drinking water [4].

Environmental As problems are commonly the result of mobilization under natural conditions, such as weathering of arsenic-bearing minerals and geothermal sources, but human activities have contributed to an important additional impact by means of mining processes, fossil fuel combustion, and the use of arsenic in pesticides, herbicides, crop desiccants, and livestock feed [5].

Dissolved As can occur in aquatic systems in both organic and inorganic forms. Inorganic As species predominate in sediments and water, but, in contrast, organoarsenic compounds prevail in marine organisms [6].

The inorganic As can be present in natural aquatic systems in four oxidation states: $+\mathrm{V}$ (arsenate), + III (arsenite), 0 (elemental As), and -III (arsine). The oxidation state is determined by $\mathrm{pH}$ and Eh. As (V) and As (III) are the common valence states in natural waters. As $(\mathrm{V})$ is the thermodynamically stable form that generally predominates in oxic surface waters, whereas As (III) is favoured in environments with low $\mathrm{pH}$ and low redox potential [7]. In natural waters and at normal $\mathrm{pHs}$, arsenate and arsenite are present as oxyanions (such as $\mathrm{H}_{2} \mathrm{AsO}_{4}{ }^{-}$and $\mathrm{HAsO}_{4}{ }^{2-}$ ) and as neutral aqueous species $\left(\mathrm{H}_{3} \mathrm{AsO}_{3}\right)$, respectively [8].

As previously mentioned, As may also occur in organic forms due to biological transformation of inorganic arsenic species. In the literature, this fact has been widely reported, 
showing that microorganisms may methylate As species as monomethylarsonic acid (MMAA), dimethylarsinic acid (DMAA), and trimethylarsine oxide (TMAO) $[9,10]$. Additionally, arsenosugars could be produced by seaweed [11], whereas arsenobetaine and arsenocholine could be produced by marine animals [12-14].

Arsenic toxicity is dependent on the chemical form in which As is presented (inorganic or organic) and on its oxidation state. Traditionally, the inorganic forms of As have been considered more toxic than the organic forms [15]. Among inorganic forms, As (III) is in general considered more toxic, soluble and mobile than As (V) [16].

In rivers, sediments act as a significant sink of As, although changes in the river flow or in other environmental conditions (Eh, $\mathrm{pH}$, and changes in water composition) may cause adsorption or desorption processes which should be controlled. In the last years, studies based on As adsorption onto sediments were reported by Rubinos et al., Bostick et al., Stollenwerk et al., Borgnino et al., and Mandal et al. [17-21]. Arsenic adsorption capacity has been related to the content of metal oxides, particularly of $\mathrm{Al}, \mathrm{Fe}$, and $\mathrm{Mn}[22,23]$, and to the clay content of sediments [5].

A significant aspect to be taken into account when As (V) adsorption is studied is the potential competition between arsenate and phosphate for surface sorption sites. Phosphate concentration has been considered a critical factor in the adsorption or release of As from solid phases [24]. Arsenate and phosphate behave both as oxyanions and present striking similarities such as quasi-identical $\mathrm{pK}_{a}$ values and charged oxygen atoms [25]. Phosphate strongly competes with As (V) for surface sites, inhibiting As (V) adsorption by Fe and $\mathrm{Al}$ oxides [26]. In the literature, the mobilization of As by $P$ from sediments has been widely reported by Kaplan and Knox, Bauer and Blodau, Stollenwerk et al., Rubinos et al., and Rubinos et al. [19, 27-30], amongst others.

The role of organisms that colonize the sediment water interface must also be taken into account. In recent years, several studies have treated the sorption and removal of arsenate by means of iron-oxidizing bacteria [31], the seaweed Lessonia nigrescens [32], and by sulphate-reducing bacteria [33]. Therefore, we hypothesize that As adsorption capacity may be affected by the presence of biofilms in the watersediment interface. Costerton (2007) defines a biofilm as a universal community of microorganisms (bacteria, fungi, cyanobacteria, algae, and protozoa) linked to wet surfaces or interfaces and embedded by a polymeric matrix (EPS) which allows an efficient water, nutrients and gas exchange between constituent populations and the outside environment [34]. Biofilms play an important role in rivers systems as they constitute the interface between the overlying water and the sediments and are the first to interact with dissolved substances such as nutrients, organic matter, and toxicants [35].

The literature and investigations on the behaviour of epipsammic biofilms on the retention of heavy metals and metalloids are scarce, so as in natural river ecosystems such as at the microcosm and mesocosm scales. Published researches, as previously mentioned, are focused on As retention by sediments and by certain isolated organism but not on the whole river bed system with the presence of multispecies biofilms, which will be one of the objectives of this study.

In this work, the effect of epipsammic biofilms developed over riverbed sediments on As retention is evaluated as well as their environmental role in river systems with presence of problematic As (V) concentrations. The capacity of As (V) retention of biofilm-sediment systems will be compared to that of the sediment without biofilm, as well as the potential remobilization produced after the retention. The effect of the biofilm on As retention in the presence of equimolar $\mathrm{P}$ concentrations was also assessed.

\section{Materials and Methods}

2.1. Sediment Sample. The sediment sample was obtained in the Anllóns River, in a noncontaminated area upstream of the town of Carballo. A complex sample was collected with a small plastic shovel from the top $5 \mathrm{~cm}$ at various points at the same site and taken to the laboratory in hermetic plastic containers topped up to prevent oxidation. The Anllóns basin is located in the NW of Spain and was selected because gold mining activities were carried out in the area during the Roman Empire and between 1895 and 1910 [36]. Arsenopyrite associated to Au produced elevated As concentrations in the bed sediments downstream the mineralized areas $[17,29,30$, 36]. Nowadays, the exploitation of the mineralized area is under study, causing social concern and controversy among the locals.

\subsection{Sediment and River Water Characterization. Grain} size distribution of the sediment was determined as it was described by Guitián and Carballas, and the fractions were classified as coarse sand $(2-0.2 \mathrm{~mm})$, fine sand $(0.2-0.05 \mathrm{~mm})$, coarse silt $(0.05-0.02 \mathrm{~mm})$, fine silt $(0.02-$ $0.002 \mathrm{~mm})$, and clay $(<0.002 \mathrm{~mm})$ [37]. Total $\mathrm{P}\left(\mathrm{P}_{T}\right)$ was determined by acid digestion $\left(\mathrm{HF}, \mathrm{H}_{2} \mathrm{SO}_{4}, \mathrm{HCl}, 10: 1: 10\right)$ followed by colorimetric determination with molybdenum blue, as described by Murphy and Riley [38].

Nitrogen was determined by wet digestion with $\mathrm{H}_{2} \mathrm{SO}_{4}$, by using the Kjeldahl method as described in Guitián and Carballas [37]. The concentration of total organic carbon (TOC) of the samples was determined according to the procedure proposed by Sauerlandt and modified by Guitián and Carballas [37], in an automatic titration system.

Sediment native As concentration was determined by Xray fluorescence spectrometry (custom built, equipped with a Philips high-voltage generator and a Mo anade of $2.2 \mathrm{~kW}$ as X-ray source), following the method described by DevesaRey et al. [36]. The concentration of $\mathrm{Al}, \mathrm{Fe}$, and $\mathrm{Mn}$ was also determined.

River water was collected and filtered by $0.45 \mu \mathrm{m}$ to be employed as biofilm growth medium in the laboratory in order to better reproduce the natural conditions for biofilm growth. $\mathrm{pH}$ and conductivity were determined, as well as soluble $\mathrm{P}$ by means of an acid digestion with $\mathrm{H}_{2} \mathrm{SO}_{4}$ followed by colorimetric determination with ammonium molybdate [39]. 
2.3. Native Biofilm Growth. A natural biofilm was grown in indoor systems during 15 days over $8 \mathrm{~g}$ of riverbed sediment, using $60 \mathrm{~mL}$ of natural river water as nutrient supplier, in small plastic containers of $100 \mathrm{~mL}$. The samples were subjected to day-night cycles (12 h of light with 3,109 lux of intensity) to reproduce approximately the natural environmental conditions. The overlying river water was replaced each 5 days together with the addition of $0.5 \mathrm{~mL}$ of inoculum (fresh river biofilm) in order to stimulate the biofilm growth. Once the biofilm was developed, the overlying water was removed, and its total $\mathrm{P}$ was measured by acid digestion with $\mathrm{H}_{2} \mathrm{SO}_{4}$.

2.4. Arsenate Sorption Experiments. To evaluate the sorption capacity and desorption behaviour of the biofilm-sediment system, batch experiments were conducted with $8 \mathrm{~g}$ sediment and their corresponding formed biofilm. In parallel, samples without biofilm following the same treatment of the biofilmsediment samples were used as controls.

$60 \mathrm{~mL}$ of As $(\mathrm{V})$ solutions with initial concentrations $\left(C_{0}\right)$ of $0,5,25,50,100,250$, and $500 \mu \mathrm{g} \mathrm{L}^{-1}$, prepared in $0.01 \mathrm{M}$ $\mathrm{CaCl}_{2}$ solutions as background electrolyte, were added to the systems. All the experiments were carried out in triplicate. Arsenate solutions were prepared from a stock standard solution of $1000 \mathrm{mg} \mathrm{L}^{-1}$ (Panreac, Barcelona, Spain). All the samples were prepared in triplicate. The batch experiments were carried out at room temperature $\left(20 \pm 2^{\circ} \mathrm{C}\right)$. Eh and $\mathrm{pH}$ measurements were carried out with a Thermo Scientific Orion Dual Star meter with a combined Redox/ORP electrode and with a AQUAPRO $\mathrm{pH}$ electrode (Beverly, USA), respectively. After $24 \mathrm{~h}$, a pseudoequilibrium state was reached, and the overlying water was taken (pipetting without altering the system). Aliquots were filtered through a $0.45 \mu \mathrm{m}$ Whatman filter, and As concentration $\left(C_{e}\right)$ of the samples was determined by Inductively Coupled Plasma Spectrometry (ICP-MS, Varian $820 \mathrm{MS}$ ) with collision reaction interface (CRI) technology to reduce polyatomic interferences. The adsorbed As $(V)$ concentrations $\left(Q_{a d s}\right)$ for the sediment or biofilm-sediment systems were obtained by the difference between $C_{0}$ and $C_{e}$, taking into account the water volume and sediment weight.

For the study of the desorption behaviour, $60 \mathrm{~mL}$ of $0.01 \mathrm{M} \mathrm{CaCl}_{2}$ solutions were added to the previous loaded systems. After $24 \mathrm{~h}$, aliquots of the overlying water were extracted by gently pipetting. Again, the samples were filtered and As concentration measured by ICP-MS. The weight of the samples was controlled in every moment to calculate the mass of As desorbed. All the experiments were carried out at pH 5.5 adjusted by addition of $0.1 \mathrm{M} \mathrm{NaOH}$ or $\mathrm{HCl}$ solutions.

\subsection{Influence of Phosphorus Presence on Arsenate Sorption} Process. To assess the influence of $\mathrm{P}$ presence on arsenate sorption, experiments with solutions of equimolar As(V): P concentrations were carried out, using the aforementioned procedure and concentrations used for the As (V) sorption experiments. $\mathrm{P}$ solutions were obtained by dissolution of $\mathrm{KH}_{2} \mathrm{PO}_{4}$ (Panreac, Barcelona, Spain). As and $\mathrm{P}$ concentrations in the supernatants were determined by ICP-MS.
2.6. Sorption Modelling. The adsorption experimental data were fitted using a linear equation, four two-parameters models (Freundlich, Langmuir, Dubinin-Radushkevich, and Temkin), and three three-parameters models (RedlichPeterson, Sips, and Toth).

The linear equation was given by (1):

$$
Q_{e}=A C_{e}-B \text {, }
$$

where $Q_{e}$ is the adsorbed or desorbed As concentration for the sediment or biofilm-sediment system, $A$ is the slope, and $B$ is the content of native arsenic.

The Freundlich equation (2) is used to describe heterogenous systems characterized by a heterogenous factor $1 / n$ :

$$
Q_{e}=K_{f} C_{e}^{1 / n}
$$

where $K_{f}$ and $n$ are empirical constants of the Freundlich model which are referred to as the capacity and intensity of adsorption, respectively [40].

The Langmuir equation (3) assumes monolayer coverage of adsorbate over a homogenous adsorbent surface:

$$
Q_{e}=\frac{\left(Q_{\mathrm{Max}} b C_{e}\right)}{\left(1+b C_{e}\right)},
$$

where $Q_{M a x}$ is the maximum adsorption capacity of the system and b is a constant related to the energy bonds Assediment and As-biofilm sediment interface [41].

The Dubinin-Radushkevich model isotherm is generally given by (4) [42]:

$$
Q_{e}=q_{D} \exp \left(-B_{D}\left[R T \ln \left(1+\frac{1}{C_{e}}\right)\right]^{2}\right),
$$

where $B_{D}$ is related to the mean free energy of sorption per gram of the sorbate as it is transferred to the surface of the solid from infinite distance in the solution [43].

The Temkin isotherm model contains a factor which takes into the account of adsorbent-adsorbate interactions and has been generally used in the form of (5) [44]:

$$
Q_{e}=\frac{R T}{b_{T}} \ln \left(A_{T} C_{e}\right) .
$$

The Redlich-Peterson empirical equation (6) incorporates features of both Langmuir and Freundlich equations [45]. It can be applied to represent adsorption equilibrium over a wide concentration range:

$$
Q_{e}=\frac{\left(K_{R} C_{e}\right)}{\left(1+a_{R} C_{e}^{\beta}\right)} .
$$

Sips model isotherm is also called Langmuir-Freundlich isotherm [46]. At low sorbate concentrations, it reduces to a Freundlich isotherm, and at high sorbate concentrations, a monolayer sorption capacity is predicted [47]:

$$
Q_{e}=\frac{\left(K_{S} C_{e}^{1 / b_{S}}\right)}{\left(1+a_{S} C_{e}^{1 / b_{S}}\right)} .
$$


The Toth isotherm model is an empirical equation useful in describing heterogeneous adsorption systems [48]. Equation (8) exhibits the most general form of this model:

$$
Q_{e}=\frac{\left(K_{t} C_{e}\right)}{\left[\left(a_{t}+C_{e}\right)^{1 / t}\right]}
$$

The parameters of all studied models were estimated by nonlinear regression procedure employing Table Curve software (Jandel Scientific).

2.7. Statistical Analyses. Five error functions were tested in order to choose the best model to fit the experimental data. These error functions were the coefficient of determination $\left(R^{2}\right)$, sum of absolute errors (EABS), hybrid fractional error function (HYBRYD), average relative error (ARE), and Marquardt's percent standard deviation (MPSD) and were calculated employing the equations described by Foo and Hameed [49].

The adsorbed concentrations of the different studied systems were evaluated by one-factor analysis of variance (ANOVA). Critical $F$ values $(\alpha=0.05)$ were used to evaluate if the factor is significant. In the case of positive significance, post hoc analyses using the Duncan comparison test $(\alpha=0.05)$ were performed to establish statistical differences between the means (SPSS 19.0 statistical package).

2.8. Theoretical Aqueous Speciation. Visual MINTEQ V 3.0 was employed to theoretically calculate As species in the solutions and to determine their saturation degree, expressed as saturation index (SI) with respect to mineral phases, by means of thermodynamic calculations and (9):

$$
\mathrm{SI}=\log \left(\frac{\mathrm{IAP}}{K_{C}}\right),
$$

where IAP is the ionic activity product of the specific dissolution-precipitation reaction and $K_{C}$ is equilibrium constant. Negative SI indicates a mineral which has potential to dissolve, whereas positive SI shows a mineral which has thermodynamic potential to precipitate [50].

To study the influence of the $\mathrm{pH}$ and organic matter in arsenic speciation, sweeps with values between 4 and 10 and 1 and $10 \mathrm{mg} \mathrm{L}^{-1}$, respectively, were performed.

\section{Results and Discussion}

3.1. Sediment and River Water Characterization. The sediment sample collected for this study showed a predominance of the sandy fraction, with an average value of $86.3 \%$, and only $6.7 \%$ of clayey fraction. Total organic matter content for the sediment was of $13.9 \pm 0.6 \mathrm{~g} \mathrm{~kg}^{-1}$. P and $\mathrm{N}$ concentrations presented average values of $471.9 \pm 43.7$ and $629.6 \pm 98.3 \mathrm{mg} \mathrm{kg}^{-1}$, respectively. The total As concentration of sediment determined by X-ray fluorescence spectrometry was $11.8 \mathrm{mg} \mathrm{kg}^{-1}$, whereas the sediment content of $\mathrm{Al}, \mathrm{Fe}$, and Mn was 50.4, 51.9, and $1.2 \mathrm{~g} \mathrm{~kg}^{-1}$, respectively.
The values of $\mathrm{pH}$, electrical conductivity, and soluble $\mathrm{P}$ concentration in the river water were $6.87,71.80 \mu \mathrm{S} \mathrm{cm}^{-1}$, and $0.21 \mathrm{mg} \mathrm{L}^{-1}$, respectively.

3.2. Arsenate Retention. Figure 1 shows the experimental data for As (V) sorption in function of the equilibrium As concentrations in the solution for the sediment and biofilm-sediment systems. $Q_{a d s}$ increased with increasing initial concentrations in all cases, thus indicating that the adsorption was not at its maximum. The values of $Q_{a d s}$ for sediment system without biofilm are in the range of the data reported by Stollenwerk et al. [19] and Borgnino et al. [20] but slightly lower because they used a different ratio (solution/sediment), lower native As concentrations in sediments, and higher added As concentrations.

It is noteworthy that $Q_{\mathrm{ads}}$ values for the samples with biofilm were higher than for the samples without biofilms. The average percentage of As adsorbed with respect to $C_{0}$ for the sediment and biofilm-sediment system was $78.9 \pm 3.5$ and $96.9 \pm 6.6 \%$, respectively. The difference between $Q_{\text {ads }}$ for the biofilm-sediment system and for the sediment without biofilm increased in the range of studied concentrations from $6.81 \times 10^{-3}$ up to $4.69 \times 10^{-1} \mu \mathrm{gg}^{-1}$ and was significant from As solutions of concentrations $\geq 50 \mu \mathrm{g} \mathrm{L}^{-1}$. This may be explained by an increase in the specific surface area and the number of sorption sites and functional groups due to the presence of the biofilm, as well as arsenate biouptake by microorganisms which constitute the biofilm. Arsenate could enter cells through phosphate-transporting systems [51]. Arsenate bioaccumulation and biouptake in green algae was studied by Karadjova et al. [52] and by Wang et al. [53]. Karadjova et al. [52] reported that intracellular As increased linearly when As (V) concentrations increased up to $50 \mu \mathrm{M}$, followed by a single saturation plateau.

Studies about As retention onto episammic biofilm have not been reported. However, the removal of heavy metals by means of bacteria biofilm has been widely and successfully studied. For example, a biofilm of Arthrobacter viscosus was applied to remove $\mathrm{Cr}(\mathrm{VI}), \mathrm{Cd}(\mathrm{II})$, and $\mathrm{Ni}(\mathrm{II})$ [43, 54-56] whereas a biofilm of Pseudomonas aeruginosa was employed to the removal of $\mathrm{Cr}(\mathrm{III}), \mathrm{Ni}(\mathrm{II})$, and $\mathrm{Co}(\mathrm{II})$ [57].

These results highlight the important role that biofilms may play in river environments by increasing As (V) retention. Biofilms could promote As sequestration from the water column; therefore, they could be potentially employed as a bioremediation tool for contaminated waters due to the larger surface area of the biofilm, with more functional groups where As can be adsorbed.

Figure 2 presents $Q_{\text {ads }}$ for As, in the presence of equimolar $P$ for the sediment and biofilm-sediment systems. Again, $Q_{\text {ads }}$ values for the biofilm-sediment system were higher than for sediment without biofilm. The difference between $Q_{\text {ads }}$ for both systems increased in the range of studied concentrations from 0.00 up to $1.56 \mu \mathrm{gg}^{-1}$ and was significant again from

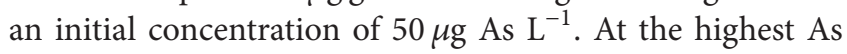
concentration, this difference was three times higher than in the experiments without $\mathrm{P}$. This behaviour could be attributed to the $\mathrm{P}$ presence which caused a significant reduction on 
As (V) adsorbed by the sediment without biofilm (a $25 \%$ reduction at the highest added As concentrations), whereas no significant effect was detected in systems where biofilm took part.

The competition between phosphate and arsenate for sorption sites in sediments has been widely reported. Thus, for example, Stollenwerk et al. [19] reported that for concentrations of As (V) of $100 \mu \mathrm{g} \mathrm{L}^{-1}$, the presence of $2 \mathrm{mg} \mathrm{L}^{-1}$ of phosphate completely inhibited As (V) adsorption. Rubinos et al. [29] also showed that the addition of increasing concentrations of phosphate enhanced the As (V) release from sediments of the Anllóns River, and, in the same line, Rubinos et al. [30] confirmed that P increased the As mobilization from these sediments in a wide range of $\mathrm{pH}(3-10)$. Nevertheless, data have not been reported about the effect of $\mathrm{P}$ on As (V) sorption in the presence of biofilms. In this study, no significant effect of phosphate in As concentration of the overlying water was observed in systems with biofilm, which could be explained by the increase of sorption sites promoted by the biofilm and/or by the increase of intracellular arsenic uptake by microorganisms which constitute the biofilm.

Desorption processes were negligible at the lowest and middle concentrations in all the studied systems and represented less than $0.5 \%$ of the sorbed As concentrations at the highest initial As concentration.

3.3. Sorption Modelling. Figures 1 and 2 showed the sorption curves for all the studied systems with their corresponding fits. Sorption isotherms were of type I according to Brunauer's classification [58]. Table 1 shows the parameters for the different tested models. According to them, sorption data were satisfactorily adjusted by all the models. The values of the parameter $A$ of the linear model were higher for the biofilmsediment systems, especially in the presence of phosphate, while the lowest was obtained for sediment without biofilm in the presence of $\mathrm{P}$.

The equilibrium arsenic concentration (EAC) is defined analogously to equilibrium phosphorous concentration (EPC) as the concentration of As that is supported by the sediment when in contact with an ambient solution such that no arsenate is either gained or lost by the sediment [17]. When As concentrations in water are higher than EAC, the sediment would act as a sink for As, whereas for water As concentrations lower than EAC, the sediment would act as a source of As. Calculated EAC values ranged from 2.62 to $18.28 \mu \mathrm{g} \mathrm{L}^{-1}$; the lowest EAC corresponded to the biofilm-sediment system with $\mathrm{P}$ and the highest to the sediment system with $\mathrm{P}$, thus pointing to a higher risk of As transfer towards the water column.

Among the analysed two-parameters models, the Freundlich model was considered the most suitable to fit experimental data in all cases; the highest $R^{2}$ values and the lowest values of other error functions are shown (Table 2). The better fits of Freundlich model are indicative of the heterogeneous surface of the solid phases studied. Langmuir model also successfully adjusted the experimental data, with $R^{2}$ values above 0.92 in all cases, whereas the Dubinin-Radushkevich and Temkin models were not completely satisfactory.

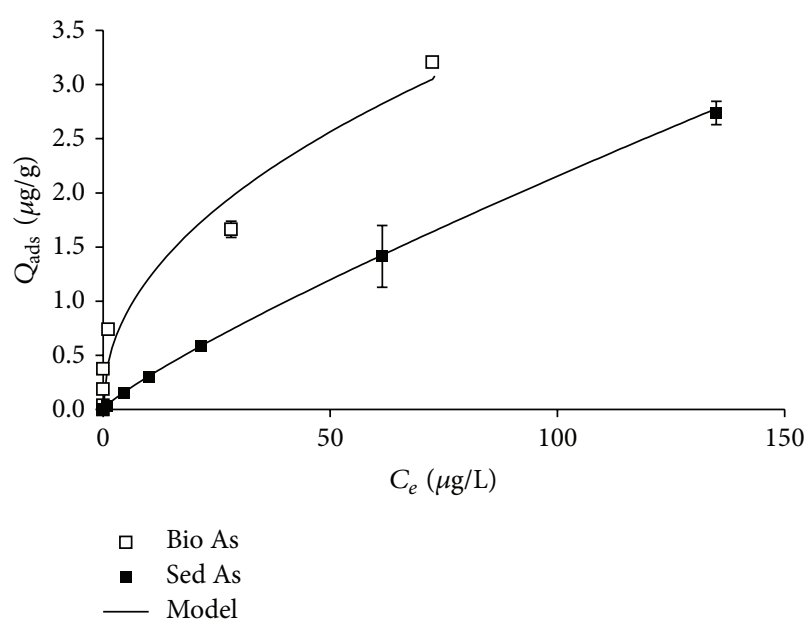

Figure 1: As (V) retention by biofilm-sediment and sediment systems in function of dissolved As equilibrium concentration.

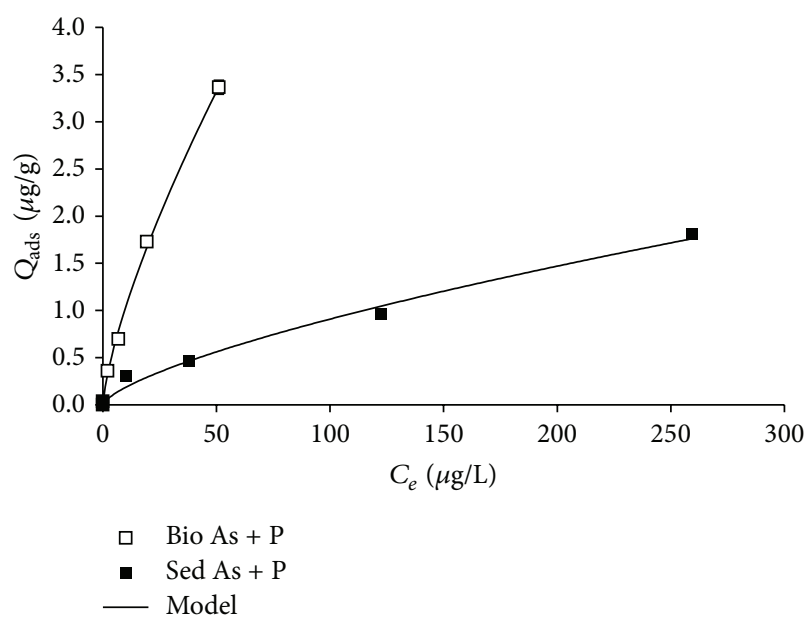

Figure 2: As (V) retention for biofilm-sediment and sediment systems in function of dissolved As equilibrium concentration in the presence of equimolar $\mathrm{P}$ concentrations.

The estimated maximum adsorption capacity of the sediment and biofilm-sediment systems, obtained from the Langmuir model, was 6.6 and $6.8 \mu \mathrm{g} \mathrm{g}^{-1}$, respectively, and 4.5 and $7.8 \mu \mathrm{g} \mathrm{g}^{-1}$, respectively, in the presence of $\mathrm{P}$. These values fall within the range of, but slightly lower than, those reported by Stollenwerk et al. [19] when studying As adsorption oxidized aquifer sediments. Again, these results highlight the key effect that the presence of biofilm causes in the fate of As in the river system, mainly in the presence of $\mathrm{P}$.

The essential characteristics of the Langmuir isotherm can be expressed in terms of an equilibrium parameter, $R_{L}$, which allows to determine if the adsorption process is favourable or unfavourable [59]. Equation (10) shows the relationship between $R_{L}$ and $C_{0}$ :

$$
R_{L}=\frac{1}{\left(1+b C_{0}\right)}
$$


TABLE 1: Parameters of theAs(V) sorption models.

\begin{tabular}{|c|c|c|c|c|}
\hline & $\begin{array}{c}\text { Sediment } \\
\text { As }(V)\end{array}$ & $\begin{array}{c}\text { Biofilm } \\
\text { As }(V)+P\end{array}$ & $\begin{array}{c}\text { Sediment } \\
\text { As }(\mathrm{V})\end{array}$ & $\begin{array}{c}\text { Biofilm } \\
\text { As }(\mathrm{V})+\mathrm{P}\end{array}$ \\
\hline \multicolumn{5}{|l|}{ Linear } \\
\hline$A$ & $2.02 \times 10^{-2}$ & $6.60 \times 10^{-3}$ & $4.15 \times 10^{-2}$ & $6.51 \times 10^{-2}$ \\
\hline$B$ & $7.19 \times 10^{-2}$ & $1.21 \times 10^{-1}$ & $2.83 \times 10^{-1}$ & $1.71 \times 10^{-1}$ \\
\hline \multicolumn{5}{|c|}{ Freundlich } \\
\hline$k_{f}$ & $4.35 \times 10^{-2}$ & $3.71 \times 10^{-2}$ & $4.12 \times 10^{-1}$ & $1.91 \times 10^{-1}$ \\
\hline$n$ & 1.18 & 1.44 & 2.14 & 1.37 \\
\hline \multicolumn{5}{|c|}{ Langmuir } \\
\hline$Q_{\text {Max }}$ & 6.60 & 4.52 & 6.79 & 7.78 \\
\hline$b$ & $4.94 \times 10^{-3}$ & $2.50 \times 10^{-3}$ & $1.22 \times 10^{-2}$ & $1.49 \times 10^{-2}$ \\
\hline \multicolumn{5}{|c|}{ Dubinin-Radushkevich } \\
\hline$q_{D}$ & 3.23 & 1.54 & 3.614 & 3.72 \\
\hline$B_{D}$ & $5.07 \times 10^{-4}$ & $3.50 \times 10^{-4}$ & $1.04 \times 10^{-4}$ & $4.73 \times 10^{-5}$ \\
\hline \multicolumn{5}{|l|}{ Temkin } \\
\hline$A_{T}$ & 2.48 & $1.28 \times 10^{-1}$ & 2.94 & $4.79 \times 10^{-1}$ \\
\hline$b_{T}$ & $4.93 \times 10^{3}$ & $5.68 \times 10^{3}$ & $4.84 \times 10^{3}$ & $2.66 \times 10^{3}$ \\
\hline \multicolumn{5}{|c|}{ Redlich-Peterson } \\
\hline$k_{r}$ & $6.00 \times 10^{-2}$ & $3.87 \times 10^{5}$ & $1.25 \times 10^{6}$ & $7.80 \times 10^{5}$ \\
\hline$a_{r}$ & $5.59 \times 10^{-1}$ & $1.04 \times 10^{7}$ & $3.11 \times 10^{6}$ & $4.07 \times 10^{6}$ \\
\hline$B$ & $2.56 \times 10^{-1}$ & $3.05 \times 10^{-1}$ & $5.32 \times 10^{-1}$ & $2.70 \times 10^{-1}$ \\
\hline \multicolumn{5}{|l|}{ Toth } \\
\hline$k_{t}$ & $4.69 \times 10^{-2}$ & $5.32 \times 10^{-2}$ & $2.59 \times 10^{-1}$ & $1.97 \times 10^{-1}$ \\
\hline$a_{t}$ & 3.91 & $6.02 \times 10^{-3}$ & $3.62 \times 10^{-2}$ & $3.60 \times 10^{-1}$ \\
\hline$t$ & 5.89 & 2.68 & 2.43 & 3.62 \\
\hline \multicolumn{5}{|l|}{ Sips } \\
\hline$k_{s}$ & $4.09 \times 10^{-2}$ & $1.04 \times 10^{-1}$ & $1.07 \times 10^{-2}$ & $3.45 \times 10^{-2}$ \\
\hline$a_{s}$ & 1.15 & 4.28 & 330.52 & 66.13 \\
\hline$b_{s}$ & $7.18 \times 10^{-4}$ & $-2.15 \times 10^{-1}$ & $-9.84 \times 10^{-1}$ & $-9.32 \times 10^{-1}$ \\
\hline
\end{tabular}

The values of $R_{L}$ ranged between 0 and 1 for all the analyzed concentrations, which corresponds to a high affinity favorable adsorption process, being more favorable at the highest initial As concentrations. As it could be seen in Figure 3, the biofilmsediment systems in the presence of phosphate present the highest affinity for As (the lowest $R_{L}$ ), whereas the sediments in the presence of phosphate show the lowest one (the highest $\left.R_{L}\right)$.

Gibbs free energy of adsorption process could be obtained from Langmuir and Temkin models by means of (11) and (12), respectively:

$$
\begin{gathered}
\ln \left(\frac{1}{b}\right)=\frac{\Delta G^{0}}{R T}, \\
\ln \left(\frac{1}{A_{T}}\right)=\frac{\Delta G^{0}}{R T} .
\end{gathered}
$$

The values of Gibbs free energy yield negative values in all cases, which indicate that the adsorption process was always spontaneous. The biofilm-sediment system in the presence of $\mathrm{P}$ showed the most negative value by applying (11) $\left(-34.50 \mathrm{~kJ} \mathrm{~mol}^{-1}\right)$ and (12) $\left(-43.10 \mathrm{~kJ} \mathrm{~mol}^{-1}\right)$, whereas the sediment system with $\mathrm{P}$ presented the least negative value

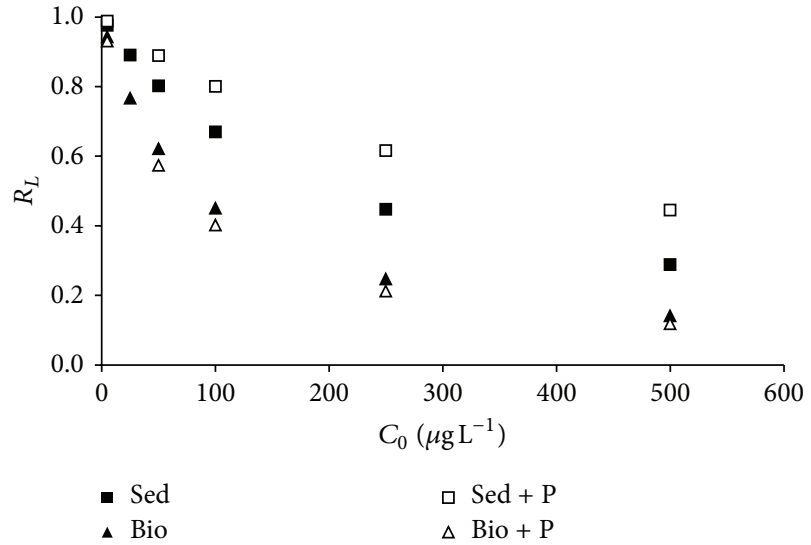

FIgURE 3: $R_{L}$ values for all studied systems in function of initial As concentrations.

$\left(-30.08 \mathrm{~kJ} \mathrm{~mol}^{-1}\right.$ by (11) and $-39.83 \mathrm{~kJ} \mathrm{~mol}^{-1}$ by (12)). The systems without $\mathrm{P}$ showed an intermediate behaviour, having more spontaneous As (V) retention in biofilm-sediment system. Therefore, the presence of biofilms jointly with $\mathrm{P}$ presence suggests that As retention process was more favoured. 
TABLE 2: Values of error functions for each model and for each analysed system.

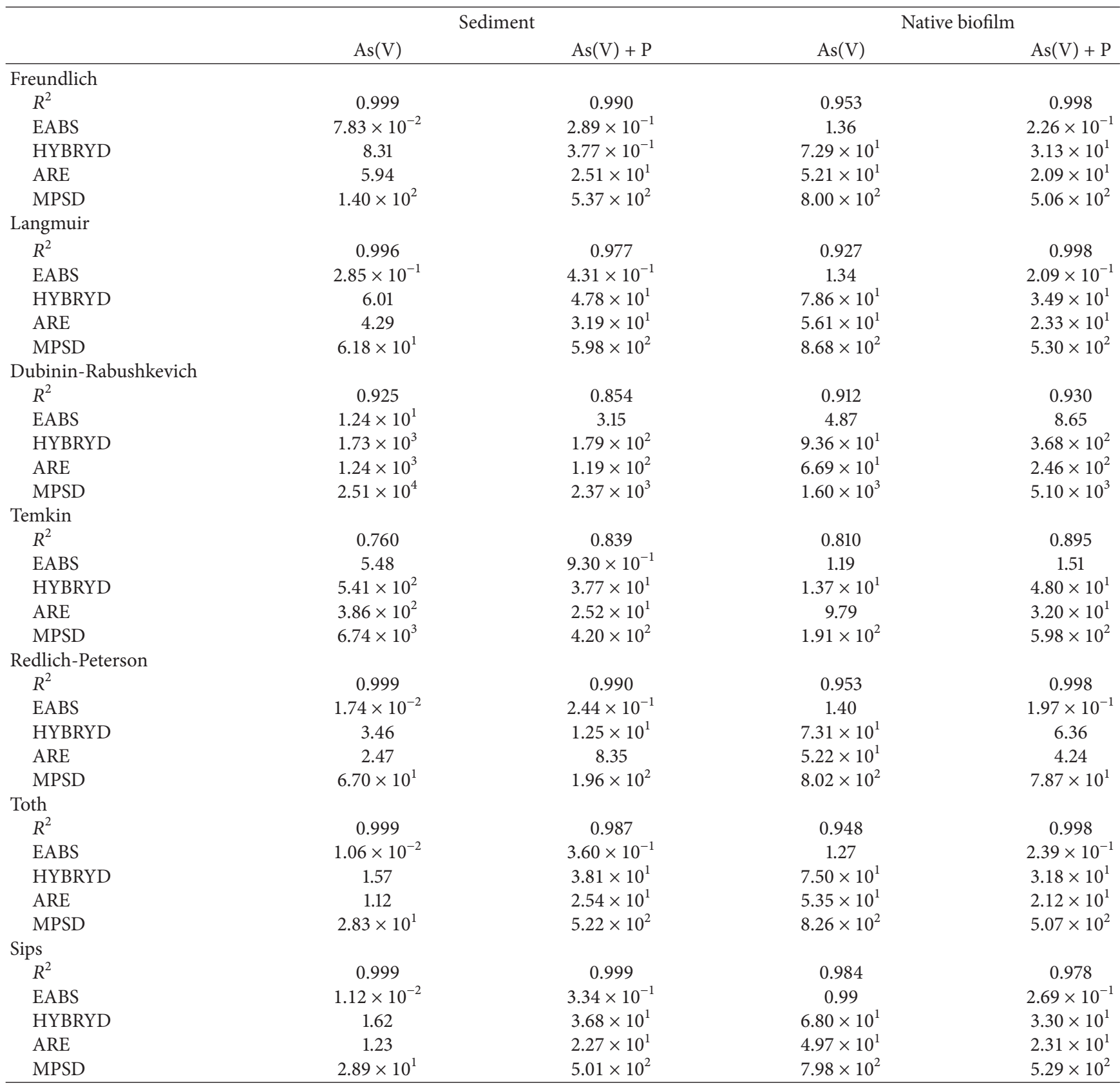

Table 2 shows also that the three-parameters models, especially Sips and Toth models, also satisfactorily fit the experimental data based on the high $R^{2}$ values $(>0.95)$ and low values of the error functions.

3.4. Theoretical Aqueous Speciation. The calculations performed by Visual MINTEQ indicated that in the studied systems, arsenic was present as inorganic As (V), with approximately $95 \%$ of total species present as $\mathrm{H}_{2} \mathrm{AsO}_{4}{ }^{-}$. Negative values of SI were found in all studied cases, which indicated that the conditions are not favourable for the precipitation of As minerals. At $\mathrm{pH} 4$, the monovalent $\mathrm{H}_{2} \mathrm{AsO}_{4}{ }^{-}$species prevails (approximately $98 \%$ of total aqueous As), whereas at
$\mathrm{pH} 10$, the bivalent $\mathrm{HAsO}_{4}{ }^{2-}$ species prevails (approximately $96 \%$ of the total aqueous As). In the studied conditions, the calculations did not predict significant complexation of As with the dissolved organic matter.

\section{Conclusions}

The biofilm increases the As (V) sorption capacity of the studied sediment. An input of P, at equimolar P: As concentrations, reduces the sorption of As (V) on the sediment, whereas no significant effect is exhibited by systems with biofilm. The Freundlich model is the best, amongst the two-parameters models, to fit the As retention in these 
systems, which is indicative of their heterogeneous surface. The sorption of As is spontaneous and favourable in all cases, especially under the combined effect of biofilm and $\mathrm{P}$, whereas the desorption this As retained is not significant. Overall, epipsammic biofilms play a key role in the fate and mobility of As in riverine environments and particularly in the transference of As from the water column to the sediment. They seem to enhance the sorption capacity and the affinity of the sediments for As, especially in environments where both As and $\mathrm{P}$ occur simultaneously.

\section{Nomenclature}

$a_{R}:$ Redlich-Peterson model parameter $(6)\left({\left.\mathrm{L} \mu \mathrm{g}^{-1}\right)}^{-1}\right.$

$a_{S}$ : Sips model parameter (7) $\left({\left.\mathrm{L} \mu \mathrm{g}^{-1}\right)}^{-1}\right.$

$a_{t}$ : Toth model parameter $(8)\left(\mu \mathrm{g} \mathrm{g}^{-1}\right)$

A: Linear model parameter (1) $\left(\mathrm{L} \mathrm{g}^{-1}\right)$

$A_{T}$ : Temkin isotherm equilibrium binding constant $\left(\mathrm{L} \mu \mathrm{g}^{-1}\right)(5)$

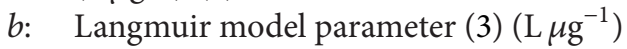

$b_{S}$ : Sips model parameter (7) (-)

$b_{T}$ : Temkin model parameter (5)

$B$ : Linear model parameter (1) $\left(\mu \mathrm{g} \mathrm{g}^{-1}\right)$

$B_{D}$ : Dubinin-Radushkevich parameter (4)

$C_{e}$ : Solution pseudoequilibrium concentration $\left(\mathrm{mg} \mathrm{L}^{-1}\right)$

$C_{0}$ : Solution initial concentration $\left(\mu \mathrm{g} \mathrm{L}^{-1}\right)$

$k_{f}$ : Freundlich model parameter $(2)\left(\mathrm{L} \mathrm{g}^{-1}\right)$

$K_{S}:$ Sips model parameter $(7)\left({\left.\mathrm{L} \mu \mathrm{g}^{-1}\right)}^{-1}\right.$

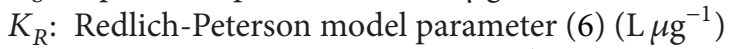

$K_{t}$ : Toth model parameter $(8)\left({\left.\mathrm{L} \mu \mathrm{g}^{-1}\right)}^{-1}\right.$

$n$ : Freundlich model parameter (2) (-)

$q_{D}: \quad$ Dubinin-Radushkevich model parameter (4) $\left(\mu \mathrm{gg}^{-1}\right)$

$Q_{\text {ads }}$ : Adsorbed concentration by sediment or biofilm-sediment interface $\left(\mu \mathrm{g} \mathrm{g}^{-1}\right)$

$Q_{\text {des }}$ : Desorbed concentration by sediment or biofilm-sediment interface $\left(\mu \mathrm{g} \mathrm{g}^{-1}\right)$

$Q_{e}: \quad$ Solid-phase equilibrium concentration $\left(\mu \mathrm{gg}^{-1}\right)$

$Q_{\text {Max }}:$ Maximum adsorption capacity $\left(\mu \mathrm{gg}^{-1}\right)$ (3)

$R_{L}$ : Langmuir equilibrium parameter (10) (-)

$t$ : $\quad$ Toth model parameter (8) (-)

T: $\quad$ Absolute temperature (K) ((4), (5), (11), and (12))

R: $\quad$ Gas constant $\left(\mathrm{J} \mathrm{mol}^{-1} \mathrm{~K}^{-1}\right)((4),(5),(11)$, and (12)).

\section{Greek Letters}

$\beta$ : Redlich-Peterson parameter (6) (-).

\section{Acknowledgments}

The authors wish to thank the financial support for the Spanish Ministry of Economy and Competitiveness (MICINN,
CGL2010-22059). Diego Martiñá Prieto wishes to acknowledge the financial support of the Spanish Ministry of Economy and Competitiveness for his FPI Fellowship (BES2011-044514). David Rubinos wishes to acknowledge the financial support of the Xunta de Galicia (Plan Galego de Investigación, Innovación e Crecemento-I2C, Consellería de Educación e Ordenación Universitaria) and the European Social Fund. Additionally, the authors also wish to thank the support of the lab technician Montserrat Recarey Pérez.

\section{References}

[1] P. Rosen, "Theoretical significance of arsenic as a carcinogen," Journal of Theoretical Biology, vol. 32, no. 2, pp. 425-426, 1971.

[2] D. K. Nordstrom, "Worldwide occurrences of arsenic in ground water," Science, vol. 296, no. 5576, pp. 2143-2145, 2002.

[3] H. M. Anawar, J. Akai, K. M. G. Mostofa, S. Safiullah, and S. M. Tareq, "Arsenic poisoning in groundwater: health risk and geochemical sources in Bangladesh," Environment International, vol. 27, no. 7, pp. 597-604, 2001.

[4] WHO, Guidelines For Drinking Water Quality, Geneva, Switzerland, 2nd edition, 1993.

[5] P. L. Smedley and D. G. Kinniburgh, "A review of the source, behaviour and distribution of arsenic in natural waters," Applied Geochemistry, vol. 17, no. 5, pp. 517-568, 2002.

[6] K. A. Francesconi, D. A. Hunter, B. Bachmann, G. Raber, and W. Goessler, "Uptake and transformation of arsenosugars in the shrimp Crangon," Applied Organometallic Chemistry, vol. 13, no. 10, pp. 669-679, 1999.

[7] H. Genç-Fuhrman, J. C. Tjell, and D. McConchie, "Adsorption of arsenic from water using activated neutralized red mud," Environmental Science and Technology, vol. 38, no. 8, pp. 24282434, 2004.

[8] L. C. D. Andersen and K. W. Bruland, "Biogeochemistry of arsenic in natural waters: the importance of methylated species," Environmental Science and Technology, vol. 25, no. 3, pp. 420427, 1991.

[9] A. A. Duker, E. J. M. Carranza, and M. Hale, "Arsenic geochemistry and health," Environment International, vol. 31, no. 5, pp. 631-641, 2005.

[10] D. Páez-Espino, J. Tamames, V. De Lorenzo, and D. Cánovas, "Microbial responses to environmental arsenic," BioMetals, vol. 22, no. 1, pp. 117-130, 2009.

[11] J. S. Edmonds and K. A. Francesconi, "Arseno-sugars from brown kelp (Ecklonia radiata) as intermediates in cycling of arsenic in a marine ecosystem," Nature, vol. 289, no. 5798, pp. 602-604, 1981.

[12] J. S. Edmonds, K. A. Francesconi, J. R. Cannon, C. L. Raston, B. W. Skelton, and A. H. White, "Isolation, crystal structure and synthesis of arsenobetaine, the arsenical constituent of the western rock lobster panulirus longipes cygnus George," Tetrahedron Letters, vol. 18, no. 18, pp. 1543-1546, 1977.

[13] H. Norin, R. Ryhage, A. Christakopoulos, and M. Sandstrom, "New evidence for the presence of arsenocholine in shrimps (Pandalus borealis) by use of pyrolysis gas chromatography: atomic absorption spectrometry/mass spectrometry," Chemosphere, vol. 12, no. 3, pp. 299-315, 1983.

[14] S. X. C. Le, W. R. Cullen, and K. J. Reimer, "Speciation of arsenic compounds in some marine organisms," Environmental Science and Technology, vol. 28, no. 9, pp. 1598-1604, 1994. 
[15] J. C. Ng, "Environmental contamination of arsenic and its toxicological impact on humans," Environmental Chemistry, vol. 2, no. 3, pp. 146-160, 2005.

[16] S. Wang and C. N. Mulligan, "Natural attenuation processes for remediation of arsenic contaminated soils and groundwater," Journal of Hazardous Materials, vol. 138, no. 3, pp. 459-470, 2006.

[17] D. Rubinos, M. T. Barral, B. Ruíz et al., "Phosphate and arsenate retention in sediments of the Anllóns river (northwest Spain)," Water Science and Technology, vol. 48, no. 10, pp. 159-166, 2003.

[18] B. C. Bostick, C. Chen, and S. Fendorf, "Arsenite retendion mechanisms within estuarine sediments of Pescadero, CA," Environmental Science and Technology, vol. 38, no. 12, pp. 32993304, 2004.

[19] K. G. Stollenwerk, G. N. Breit, A. H. Welch et al., "Arsenic attenuation by oxidized aquifer sediments in Bangladesh," Science of the Total Environment, vol. 379, no. 2-3, pp. 133-150, 2007.

[20] L. Borgnino, C. P. de Pauli, and P. J. Depetris, "Arsenate adsorption at the sediment-water interface: sorption experiments and modelling," Environmental Earth Sciences, vol. 65, no. 2, pp. 441451, 2012.

[21] S. K. Mandal, N. Majumder, C. Chowdhury, D. Ganguly, M. Dey, and T. K. Jana, "Adsorption kinetic control of As(III \& V) mobilization and sequestration by Mangrove sediment," Environmental Earth Sciences, vol. 65, no. 7, pp. 2027-2036, 2012.

[22] R. De Vitre, N. Belzile, and A. Tessier, "Speciation and adsorption of arsenic on diagenetic iron oxyhydroxides," Limnology \& Oceanography, vol. 36, no. 7, pp. 1480-1485, 1991.

[23] K. A. Sullivan and R. C. Aller, "Diagenetic cycling of arsenic in Amazon shelf sediments," Geochimica et Cosmochimica Acta, vol. 60, no. 9, pp. 1465-1477, 1996.

[24] F. Liu, A. De Cristofaro, and A. Violante, "Effect of pH, phosphate and oxalate on the adsorption/desorption of arsenate on/from goethite," Soil Science, vol. 166, no. 3, pp. 197-208, 2001.

[25] E. H. Larsen and S. H. Hansen, "Separation of arsenic species by ion-pair and ion exchange high performance liquid chromatography," Mikrochimica Acta, vol. 109, no. 1-4, pp. 47-51, 1992.

[26] B. A. Manning and S. Goldberg, "Modeling competitive adsorption of arsenate with phosphate and molybdate," Environmental Science and Technology, vol. 31, pp. 2005-2011, 1996.

[27] D. I. Kaplan and A. S. Knox, "Enhanced contaminant desorption induced by phosphate mineral additions to sediment," Environmental Science and Technology, vol. 38, no. 11, pp. 31533160, 2004.

[28] M. Bauer and C. Blodau, "Mobilization of arsenic by dissolved organic matter from iron oxides, soils and sediments," Science of the Total Environment, vol. 354, no. 2-3, pp. 179-190, 2006.

[29] D. Rubinos, L. Iglesias, R. Devesa-Rey, F. Díaz-Fierros, and M. T. Barral, "Arsenic release from river sediments in a gold-mining area (Anllóns River basin, Spain): effect of time, $\mathrm{pH}$ and phosphorous concentration," European Journal of Mineralogy, vol. 22, no. 5, pp. 665-678, 2010.

[30] D. A. Rubinos, L. Iglesias, F. Díaz-Fierros, and M. T. Barral, "Interacting effect of $\mathrm{pH}$, phosphate and time on the release of arsenic from polluted river sediments (Anllóns River, Spain)," Aquatic Geochemistry, vol. 17, no. 3, pp. 281-306, 2011.

[31] I. A. Katsoyiannis and A. I. Zouboulis, "Application of biological processes for the removal of arsenic from groundwaters," Water Research, vol. 38, no. 1, pp. 17-26, 2004.

[32] H. K. Hansen, A. Ribeiro, and E. Mateus, "Biosorption of arsenic(V) with Lessonia nigrescens," Minerals Engineering, vol. 19, no. 5, pp. 486-490, 2006.
[33] D. Teclu, G. Tivchev, M. Laing, and M. Wallis, "Bioremoval of arsenic species from contaminated waters by sulphate-reducing bacteria," Water Research, vol. 42, no. 19, pp. 4885-4893, 2008.

[34] J. W. Costerton, The Biofilm Primer, Springer, Berlin, Germany, 2007.

[35] S. Sabater, H. Guasch, M. Ricart et al., "Monitoring the effect of chemicals on biological communities. The biofilm as an interface," Analytical and Bioanalytical Chemistry, vol. 387, no. 4, pp. 1425-1434, 2007.

[36] R. Devesa-Rey, R. Paradelo, F. Díaz-Fierros, and M. T. Barral, "Fractionation and bioavailability of arsenic in the bed sediments of the Anllóns River (NW Spain)," Water, Air, and Soil Pollution, vol. 195, no. 1-4, pp. 189-199, 2008.

[37] F. Guitián and T. Carballas, Técnicas de Análisis de Suelos, Pico Sacro, Santiago de Compostela, Spain, 1976.

[38] J. Murphy and J. P. Riley, "A modified single solution method for the determination of phosphate in natural waters," Analytica Chimica Acta, vol. 27, pp. 31-36, 1962.

[39] APHA, Standard Methods For the Examination of Water and Waste Water, The American Public Health Association, The American Water Works Association, Water Environment Federation, 21st edition, 2005.

[40] H. Freundlich, "Adsorption in solutions," Journal of Physical Chemistry, vol. 57, pp. 384-410, 1906.

[41] I. Langmuir, "The adsorption of gases on plane surfaces of glass, mica and platinum," Journal of the American Chemical Society, vol. 40, no. 9, pp. 1361-1403, 1918.

[42] M. M. Dubinin and L. V. Radushkevich, "The equation of the characteristic curve of activated charcoal," Doklady Akademii Nauk SSSR, vol. 55, pp. 327-329, 1947.

[43] C. Quintelas, B. Fonseca, B. Silva, H. Figueiredo, and T. Tavares, "Treatment of chromium(VI) solutions in a pilot-scale bioreactor through a biofilm of Arthrobacter viscosus supported on GAC," Bioresource Technology, vol. 100, no. 1, pp. 220-226, 2009.

[44] M. I. Temkin and V. Pyzhev, "Kinetics of ammonia synthesis on promoted iron catalyst," Acta Physico-Chimica Sinica, vol. 12, pp. 327-356, 1940.

[45] O. Redlich and D. L. Peterson, "A useful adsorption isotherm," Journal of Physical Chemistry, vol. 63, no. 6, p. 1024, 1959.

[46] R. Sips, "Combined form of Langmuir and Freundlich equations," The Journal of Physical Chemistry, vol. 16, pp. 490-495, 1948.

[47] C. Quintelas, B. Silva, H. Figueiredo, and T. Tavares, "Removal of organic compounds by a biofilm supported on GAC: modelling of batch and column data," Biodegradation, vol. 21, no. 3, pp. 379-392, 2010.

[48] J. Toth, "State equations of the solid-gas interface layer," Acta Chimica Academiae Scientiarum Hungaricae, vol. 69, pp. 311328, 1971.

[49] K. Y. Foo and B. H. Hameed, "Insights into the modeling of adsorption isotherm systems," Chemical Engineering Journal, vol. 156, no. 1, pp. 2-10, 2010.

[50] P. H. Simms, E. K. Yanful, L. St-Arnaud, and B. Aubé, "A laboratory evaluation of metal release and transport in flooded preoxidized mine tailings," Applied Geochemistry, vol. 15, no. 9, pp. 1245-1263, 2000.

[51] F. J. Zhao, J. F. Ma, A. A. Meharg, and S. P. McGrath, "Arsenic uptake and metabolism in plants," New Phytologist, vol. 181, no. 4, pp. 777-794, 2009.

[52] I. B. Karadjova, V. I. Slaveykova, and D. L. Tsalev, “The biouptake and toxicity of arsenic species on the green microalga 
Chlorella salina in seawater," Aquatic Toxicology, vol. 87, no. 4, pp. 264-271, 2008.

[53] N. Wang, Y. Li, X. Deng, A. Miao, R. Ji, and L. Yang, “Toxicity and bioaccumulation kinetics of arsenate in two freshwater green algae under different phosphate regimes," Water Research, vol. 47, pp. 2497-2506, 2003.

[54] C. Quintelas and T. Tavares, "Removal of chromium(Vi) and cadmium(II) from aqueous solution by a bacterial biofilm supported on granular activated carbon," Biotechnology Letters, vol. 23, no. 16, pp. 1349-1353, 2001.

[55] M. Pazos, M. Branco, I. C. Neves, M. A. Sanromán, and T. Tavares, "Removal of $\mathrm{Cr}(\mathrm{VI})$ from aqueous solutions by a bacterial biofilm supported on zeolite: optimisation of the operational conditions and scale-up of the bioreactor," Chemical Engineering and Technology, vol. 33, no. 12, pp. 2008-2014, 2010.

[56] C. Quintelas, R. Pereira, E. Kaplan, and T. Tavares, "Removal of $\mathrm{Ni}(\mathrm{II})$ from aqueous solutions by an Arthrobacter viscosus biofilm supported on zeolite: from laboratory to pilot scale," Bioresource Technology, vol. 142, pp. 368-374, 2013.

[57] S.-Y. Kang, P. J. Bremer, K.-W. Kim, and A. J. McQuillan, "Monitoring metal ion binding in single-layer Pseudomonas aeruginosa biofilms using ATR: IR spectroscopy," Langmuir, vol. 22, no. 1, pp. 286-291, 2006.

[58] S. Brunauer, L. S. Deming, W. E. Deming, and E. Teller, "On a theory of the van der Waals adsorption of gases," Journal of The American Chemical Society, vol. 62, no. 7, pp. 1723-1732, 1940.

[59] T. W. Weber and P. K. Chakarvorti, "Pore and solid diffusion models for fixed-bed adsorbers," The American Institute of Chemical Engineers, vol. 20, pp. 228-237, 1947. 

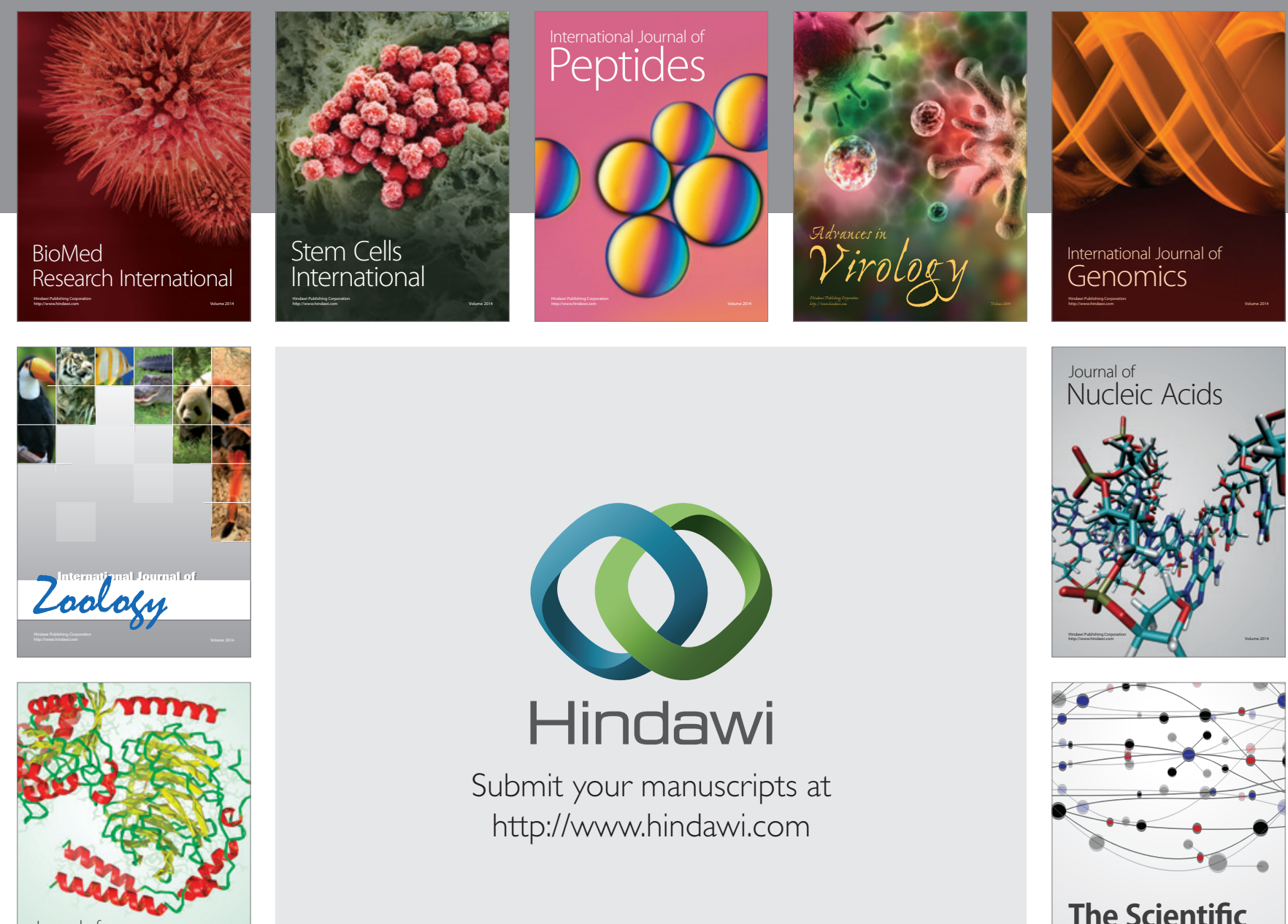

Submit your manuscripts at

http://www.hindawi.com

Journal of
Signal Transduction
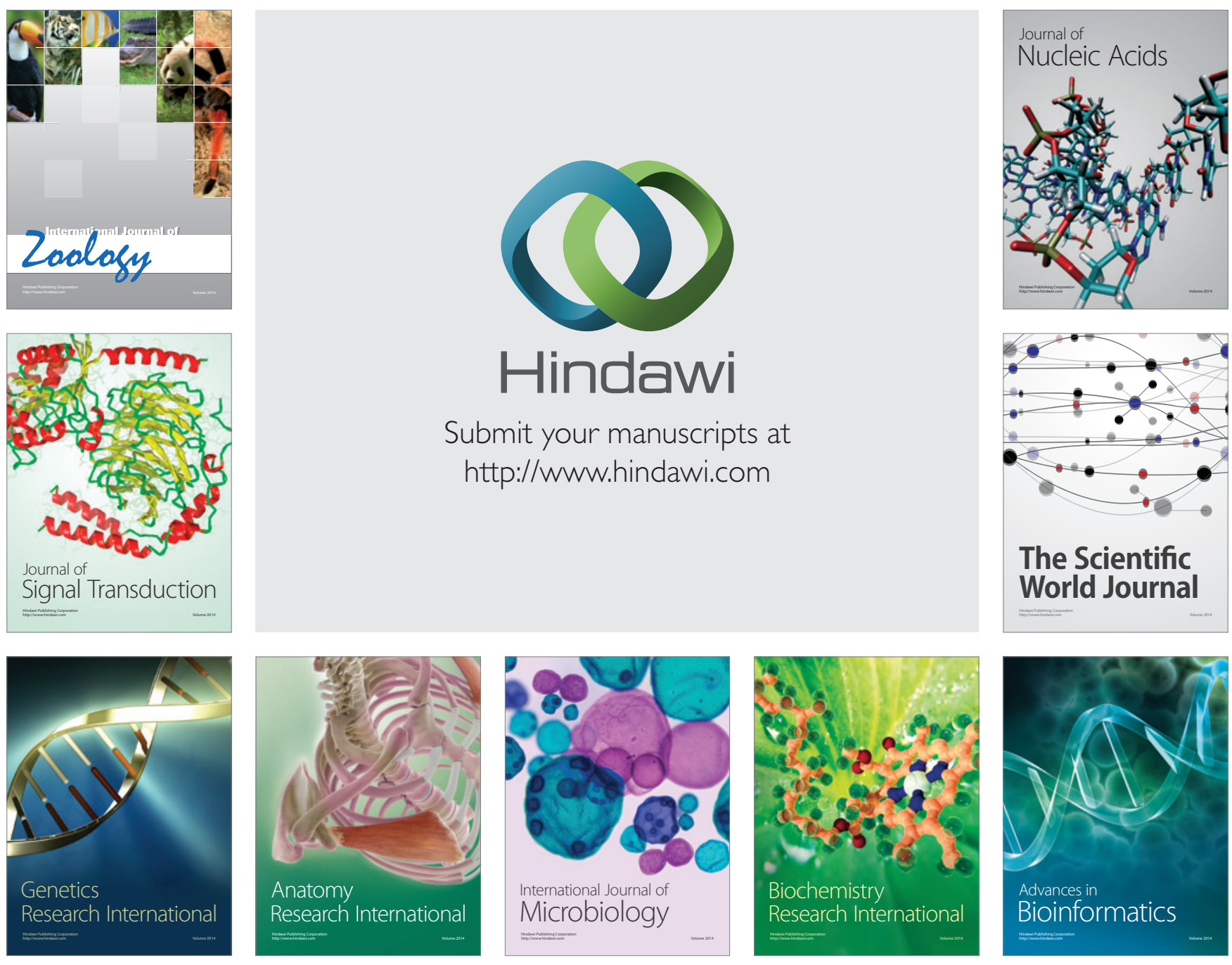

The Scientific World Journal
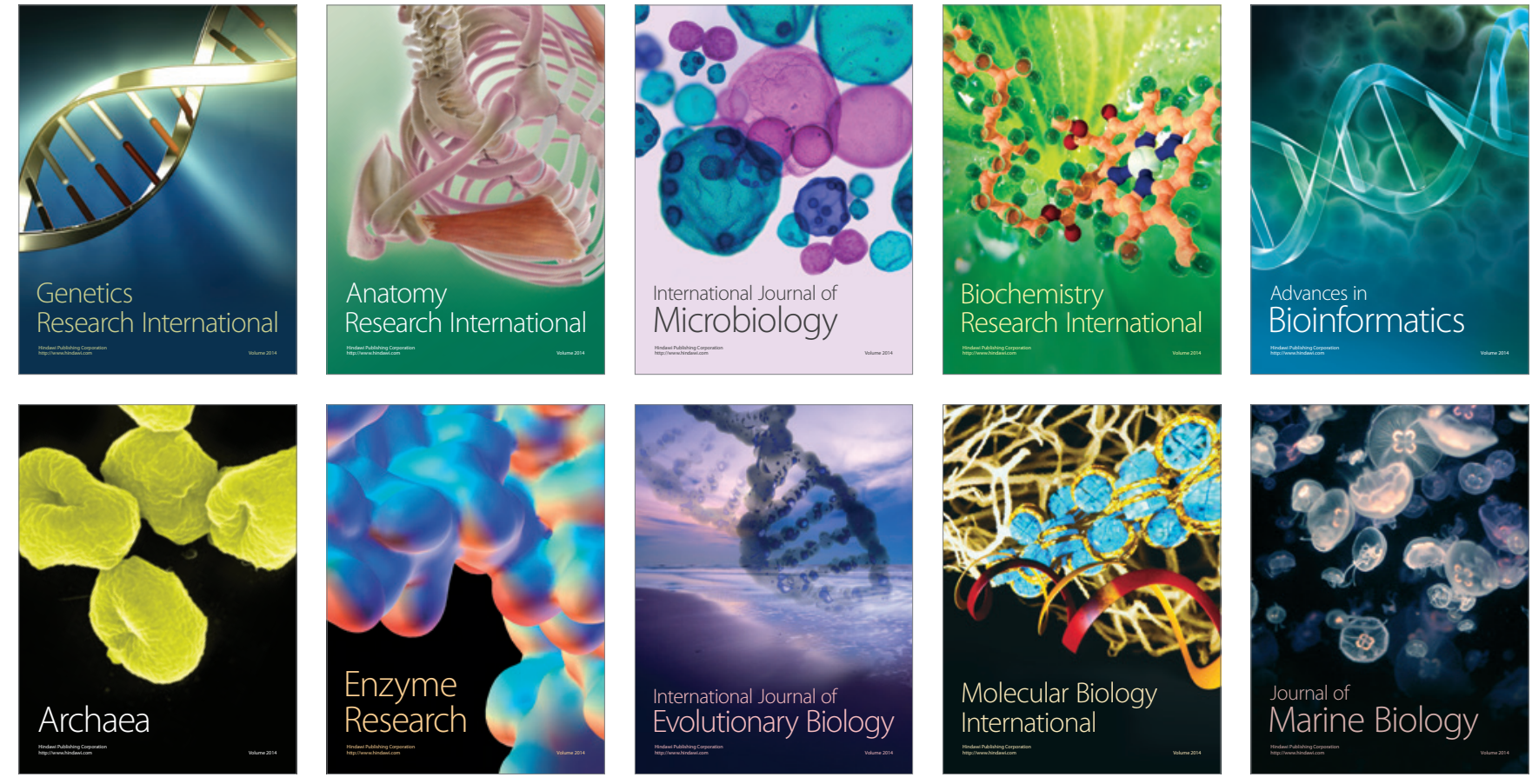